\title{
Does the differences in 6, 7, and 8-year-old children's reading and writing success has to do with diligence rather than intelligence
}

\author{
Teinye Briggs ${ }^{1}$, Nwachukwu Prince Ololube ${ }^{2}$ \\ ${ }^{1}$ Department of Applied Sciences of Education, Faculty of Behavioural Sciences, University of Helsinki, Helsinki, Finland \\ ${ }^{2}$ Department of Educational Management and Planning, Faculty of Education, Ignatius Ajuru University of Education, Rumuolumeni, Port \\ Harcourt, Nigeria
}

\section{Email address:}

teinye.briggs@yahoo.com (T. Briggs), ololubeprince@yahoo.com, ololubeno@gmail.com (N. P. Ololube)

\section{To cite this article:}

Teinye Briggs, Nwachukwu Prince Ololube. Does the Differences in 6, 7, and 8-Year-Old Children's Reading and Writing Success has to do With Diligence Rather than Intelligence. International Journal of Elementary Education. Vol. 3, No. 5, 2014, pp. 105-114.

doi: 10.11648/j.ijeedu.20140305.11

\begin{abstract}
The study is a follow up to a study that was previously conducted by the authors (Briggs, Ololube, \& Kpolovie, 2014) on "Managing Children Learning: Support Based Screening Procedure for Motor, Cognition and Language Communication in Early Childhood Education". Limited data are available that describe the relative impact of diligence and intelligence in children's reading and writing skills in sub-Saharan Africa. In today's world, young children look for attention and engage in positive or negative behavior to attain it. It is important that teachers recognize the diligence and intelligence worth of their students on a consistent basis, as research literature in education is devoting increasing attention to the role of children's effort in academic performance. This study posits two constructs: diligence and intelligence, which express or reflect individual children's efforts toward achieving reading and writing success. A Diligence and Intelligence Inventory was developed with assistance from experts to elicit data from 6, 7, and 8-year-old children's teachers on their pupils' achievements in reading and writing. Using Cronback analysis and construct validation procedures, the instrument was certified to have internal consistency. The results from 321 schoolchildren revealed a significant statistical difference between diligence and intelligence. The academic and practical implications of this study to educational practice include a greater need to complement the efforts of young children in their pursuit for balanced educational development.
\end{abstract}

Keywords: Diligence, Intelligence, Reading and Writing, Academic Success, Schoolchildren, Nigeria

\section{Introduction}

Reading and writing in children is a uniquely human activity. For children to read and write effectively, they must develop a sophisticated collection of fine, cognitive, and gross motor and language skills (Briggs, Ololube, \& Kpolovie, 2014). However, in some cases, children find reading and writing a difficult task because every child is different and learns at a different rate. Because of the differences in learning ability, Li $(2008,2005)$ argued that parents should have diligence and never push children to learn, while showering them with praise when they succeed.

The ability to read means the ability to pronounce words, identify words, and obtain their meaning, as well as to bring meaning to a text to get meaning from it (Perfetti, 2007;
Mudzielwana, 2012; Hu, 2009; Hashmi, n.d.). Reading in children is an essential means of understanding other people's ideas, and writing is a vital way for children to comprehend what they think. Therefore, our role in encouraging good communication skills is crucial (Ololube, Briggs, Kpolovie, \& Ezindu, 2010).

Surprisingly, writing is not generally encouraged in young children as much as reading is (Flynn, 2011). Friends and family give gifts of books more often than gifts of writing supplies (Ozenreider, n.d.; Flynn, 2011). Learning the letters of the alphabet and of how to read are milestones every preschooler reaches in their own time and at their own pace. To achieve these goals, both parents and teachers are involved in making sure that these milestones are reached (Ololube, Kpolovie, \& Egbozor, 2009).

According to Lyon (1995), children's developmental 
dyslexia (CDD) is often diagnosed when reading and writing achievement is not commensurate with scale, such as intellectual functioning, chronological age, or educational instruction. In defining dyslexia, dictionaries include terms, such as developmental disorders that can cause learning difficulties in one or more of the areas of reading, writing, and numeracy. Despite wide disapproval regarding the usage of the term CDD (Meyer, 2000; Siegel, 2003; Stage, Abbott, Jenkins, \& Berninger, 2003) because of inconsistencies between intellectual functioning and some measure in reading and writing achievement, CDD is still predominantly popular. CDD has been disapproved of because of poor validity, predictive power, and reliability (Flowers, Meyer, Lovato, Wood, \& Felton, 2000; Vellutino, Scanlon, \& Lyon, 2000).

In another vein, researchers (Langer, 1986a,b; Chall \& Jacobs, 1983) argued that reading, writing, and intelligence are unconnected given the assumption that complexities in reading and writing are a result of a form of highly restricted cognitive discrepancy, which may not affect children's intelligence quotient (IQ). Briggs et al. (2014), Gustafson and Samuelsson (1999), and Scarborough and Parker (2003) criticized this view by arguing that reading and writing difficulties restrict children's intelligence in many cognitive domains (e.g., debate, describing, discussion, reading, knowing, labelling, summarising, translating, and vocabulary).

Another model for determining reading ability is the Neale Analysis of Reading Ability (NARA) (Neale, 1991). This standardized reading measure developed in Australia for primary school children is been used in several other countries, making it an ideal reading measure. It comprises graded short-passages for assessing children's oral reading skills to show indices of conventional reading speed, accuracy, and comprehension. The Reading Rate provides an index of a child's normal reading speed and converts to the number of words read per minute. Reading Accuracy is the number of errors accumulated when reading the passages, and Reading Comprehension involves assessment of what the child remembers regarding the content of the passages (Cotton \& Crewther, 2009).

Sparking this public debate further on the critical importance of the early years of children's learning life, studies conducted on showing the remarkable influence of very early experience on the actual stimulation of children reading and writing development revealed that early stimulation prepares the way for later growth and development (Colbert, 2008; Ololube et al., 2009; Ololube et al., 2010). According to Colbert (2008), lack of stimulation or negative stimulation can make learning growth and development impossible or extremely difficult. He went further to state that researchers have studied how the development of the brain influences specific functions. For example, Driscoll (2001), Eliasmith (2001), and Lutz and Huitt (2003) have used information processing theory to understand memory. They defined memory system in terms of brain mechanisms, the kind of information processes, and the principles of its operation. They also looked at memory in terms of ability or faculty, which enables us to interpret the perceptual world and changes that take place in the world. Williams, Myerson, and Hale (2008) have searched for ways to define intelligence as a system and to explain how intelligence differs from individual to individual.

To Jablon and Wilkinson (2006) and Lily (n.d.), successful children schooling depends on time and diligence. Diligence is a character quality for children to learn. The benefits of diligence help child throughout their adult life. Children begin learning about diligence at a young age. Teaching a toddler how to clean up their toys is a small lesson in diligence. A young child can help pick up sticks in the yard or put away their clothes. These engagement styles of doing things are foundational to teaching diligence. The engagement strategies you choose depend on your purpose, teaching style, and the children in your classroom. Regardless of the strategies selected, effective facilitation is a key to making them work (Tough, 2011). As children get older, the real test of learning how to be diligent begins. Rewards for children's efforts at diligence no matter how small are encouraging. Encouragement is the soil for character development and growth in children. Children desire to be diligent as they see the benefits. Teaching this character quality is not easy, but it is worth the effort (Mae, 2010).

Research in the field of reading and writing, however, has not kept up with the evaluation of the debates. Despite the tremendous impact of the debates, most existing reading and writing research has been focusing primarily on the effectiveness of specific instructional methods or programs (Harrison, 2004; Song \& Young, 2008). Against this backdrop, it is presumed in this current study that the relationship between reading and writing, diligence and intelligence are fundamental to children learning differences. If the correlation between reading and writing, diligence and intelligence vary with children's learning growth and development, the psychometric elements of any child development model depend on the age of the child. The existing models may also vary depending on the measures. Considering the aforementioned factors determines the validity and reliability of the model.

Thus, a Diligence and Intelligence Inventory (DII) was developed for this study to elicit data from school teachers' on the reading and writing achievement of their pupils based on diligence and intelligence. DII measured children's reading speed, accuracy, comprehension, recognizing, vocalization, and naming. Whereas, the second part measured children's writing and their intellectual ability in defining, describing, identifying, knowing, labelling, listing, matching, outlining, recalling, reproducing, and selecting words.

Using Cronback analysis and construct validation and reliability procedures, the instrument was satisfied to have internal consistency. Therefore, the aim of the study was to determine if diligence and intelligence would be predictors of reading and writing ability for children aged from 6 to 8 
years. The DII measures of diligence and intellectual functioning based on their relative independence of children reading and writing abilities for successful academic achievement was contrasted.

The second aim was to use these measures to establish whether diligence and intelligences are correlated with measures of reading and writing ability across the 6-8 age levels. In this current study, we used a straightforward definition of reading to mean the ability to analyze, describe a mental representation of, and to comprehend what is written in print. Writing means the ability to represent what has been read from print into a logical progression for easy understanding. Based on the aims of this investigation, three hypotheses were formed:

- Diligence would be a predictor of reading and writing ability for children aged from 6 to 8 years.

- Intelligence would be a predictor of reading and writing ability for children aged from 6 to 8 years.

- The difference in 6,7, and 8-year-old children's reading and writing success usually has to do with diligence rather than intelligence

\section{Conceptualization/Literature Review}

\subsection{Diligence}

The term diligence brings to mind persistence, steady effort, hard work, and putting one's full attention and concentration into what is being done. These are all commendable qualities that would bring satisfaction if displayed in our children's attitudes. However, these attitudes are not innate and they must be taught to children (Junkere, 2009), and this will take diligence day after day, even the whole year to accomplish. If our children fail, it is our fault. If they succeed, it is our effort. The success of our home school depends on us and the time and energy we put into it. If we make it happen, it will; if we do not, it will not happen (Lily, n.d; Scruton, H., \& McNamara, 2014).

According to Japanese Education (n.d.), the Japanese, for example, believe that diligence, hard work, and perseverance yield success in education, as well as in other aspects of life. A certain amount of difficulty and hardship is believed to strengthen students' characters and their resolve to do their best in learning and other important endeavors. The amount of time and effort spent in study are believed to be more important than intelligence in determining educational outcomes. Most Japanese parents and educators are unshakably optimistic that virtually all children have the potential to master the challenging academic curriculum, provided they work hard and long enough. Some teachers and students are less sanguine. The educational results achieved by most Japanese students in international comparisons provide considerable support for the beliefs and expectations of the majority, particularly in light of the fact that there is no credible evidence that Japanese children have a higher level of native intelligence than, for example, American children (Japanese Education, n.d.). Furthermore, according to Japanese Education (n.d.), the cultural emphasis on student effort and diligence is balanced by recognition of the important responsibility borne by teachers, parents, and schools to awaken the desire to try. Japanese teachers do not believe that motivation is primarily a matter of luck, family background, or personality traits. They believe that the desire to learn-like character itself-is something teachers can shape and is influenced through the school environment. Students are unceasingly taught and urged to "do their best," in groups and as individuals.

Harrison (2004) considered these factors to be associated with avid reading; where a teacher's enthusiasm and encouragement are the greatest gifts they can share with the children they teach, for without them, any amount of resources and knowledge may be potentially profitless. However, he noted that knowledge and resources are important too. Bay (2009) was motivated by the possibilities of affecting the minds of young children. Encouraging children to become constant and earnest in their immediate goals and in their future reading and writing habits is presumed to be a predictor to children's academic achievement in reading and writing abilities. Bay (2009) emphasized that "diligence" is worth the effort and when we realize this factor, we open doors in learning and accelerate teaching.

\subsection{Intelligence}

The concept of intelligence is difficult to define precisely, but global intellectual ability is correlated with academic achievement (Stenhouse, 2009; Neisser, 1995; Neisser et al., 1996). One issue is certain; intelligence cannot precisely be measured (McGrew \& Evans, 2004). Usually children are described informally as being bright, average, or slow, as determined by their perceived intellectual ability. Interestingly, these informal assessments are usually fairly accurate, which implies that whatever intelligence may be, we can usually recognize it when we see it. It is also a fact of common observation that "bright" children are likely to do well academically and make good progress at school, averagely intelligent children will probably perform at an average level, and "slow" children will struggle and need extra help (Huttenlocher, Haight, Bryk, Seltzer \& Lyons, 1991; Stenhouse, 2009).

All children are expected to go to school, but not all children are capable of learning (Save the Children, 2002). The most common reasons for learning problems according to Save the Children (2002) and Stenhouse (2009) are:

- Below average intellectual ability;

- Specific learning difficulties;

- Attention Deficit Disorder (ADD); and

- Being male

According to Stenhouse (2009), some children have great difficulty learning to read and write despite normal intelligence and in the absence of any other factor that could impede their learning (e.g., sight or hearing problems). Some children who appear to be of at least average intelligence, who come from supportive home backgrounds 
where reading has been encouraged, who have no sight or hearing problems, and who have received appropriate and skillful teaching struggle to acquire and retain literacy skills (McLeod, 2009). The simplest and most logical explanation for the difficulties these children experience is that they have an innate, neurologically based problem with processing print, despite normal intelligence. In other words, they have a specific learning difficulties (Stenhouse, 2009).

Dyslexia literally means "difficulty with reading" but in practice, it invariably implies a difficulty with writing as well (Stenhouse, 2009). However, the majority of male children perform to expectation in the classroom, but it is a fact that males are more likely than females to have learning difficulties or to achieve at a level below their apparent potential (Younger, Warrington, Gray, Rudduck, McLellan, Bearne, Kershner, \& Bricheno, 2005). This is partly because males are more likely than female to be dyslexic or have $\mathrm{ADD}$, but also because there is a noticeable tendency for some males simply to be less interested in the language and literacy focus of most classroom activities. These male children are much more interested in sport or practical, hands-on activities, and they become increasingly bored with school. They become reluctant pupils, except for technical subjects and physical education, and are keen to leave school as soon as possible. In this case, the problem is not theirs, but is due to the fact that the education system does not suit their talents and interests (Stenhouse, 2009).

The majority of children aim to succeed in their academic activities. Yet, there is increasing evidence that the likelihood of their success is influenced not only by actual ability, but also by the quality of teaching and goals that they bring to the achievement situation (Elliot \& Dweck, 2005; Ololube et al., 2009). However, intelligence promotes better learning, memory, and growth of the intellectualism. It also enhances the development of language, spatial intelligence, and reading and writing skills. Experiments indicate that people believe intelligence can impede ability to learn (Dweck, 2006; Mangels, Butterfield, Lamb, Good, \& Dweck, 2006; Niesser et al., 1996). People who believe that intelligence is a fixed and stable trait are more likely to avoid challenges. They are also less likely to learn from their mistakes and the difference shows up in IQ tests (Dewar, 2013).

The theory of multiple intelligences is a model of intelligence that differentiates it into specific modalities, rather than seeing intelligence as dominated by a single general ability (Gardner, 1983). Gardner (1983) argued that there is a wide range of cognitive abilities, but only very weak correlations among them. For example, the theory postulates that a child who learns to read and write easily is not necessarily more intelligent than a child who has more difficulty in reading and writing task. Gardner (1983) believed that the purpose of schooling should be to develop intelligences and to help children reach reading and writing, goals that are appropriate to their particular spectrum of intelligences. According to Gardner (1983), children who are helped to do so feel more engaged and competent and therefore more inclined to academic exercise in a constructive way.

However, critics of the theory of multiple intelligences (e.g., Klein, 1997; Sternberg, 1983, 1991) have objected to its apparent lack of objective criteria, empirical evidence, and measurability, but if this has no merit, why do we sort students according to their intelligence in college? At the same time, some supporters of Gardner's (1983) ideas want every school to address all eight intelligences (Linguistic, Logical-Mathematical, Visual-Spatial, Musical, BodilyKinesthetic, Interpersonal, Intrapersonal, Naturalistic intelligence), which may seem like an admirable goal, but will almost guarantee that every student feels equally frustrated, since very few are equally intelligent in every way (Fisher, 2013; National Educational Psychological Services NEPS, 2012).

\subsection{Students' Academic Success}

Controversy trail the assessment of literacy achievement in the early years of children, and this controversy is characterised by debate about the rationale of assessment, when it should be carried out, and the most effective types of literacy assessment in the early childhood education (Carless, 2004; 2009). However, there is growing recognition that the purposes, forms, and interpretations of literacy assessments and achievements are culturally determined and reflect social values, beliefs, and practices about literacy and learning. For example, the age at which children are expected to learn to read and write differ in children, as do literacy pedagogies and policies. Nonetheless, within the assessment debate, there is broad agreement that assessment of literacy success is an important part of the early year's academic achievement (Oakley \& Barratt-Pugh, 2007).

\subsection{Intellectual Ability}

Two sets measures of reading and writing were selected to measure: The first is reading measures to test children's reading speed, accuracy, comprehension, recognizing, vocalization, and naming (Briggs et al., 2014). The second is writing measures that test children's intellectual ability in defining, describing, identifying, knowing, labelling, listing, matching, outlining, recalling, reproducing, and selecting words (Briggs et al., 2014). The measures selected for use in this study have been employed in the learning and reading difficulty literature for diagnostic purposes.

\subsection{Reading Ability Test}

Assessing reading in the early years of learning serves several purposes: it identifies children who need additional support, provides information for reporting purposes, and informs teachers of their teaching effectiveness and meeting literacy outcomes (Paris \& Hoffman, 2004). A widely used reading assessment test is the Neale Analysis of Reading Ability - Revised (NARA) (Neale, 1999). The purpose of the NARA is to measure the accuracy, comprehension, and rate of reading, to monitor reading progress, and to obtain diagnostic observations of reading behaviour. The NARA 
provides standardized scores; reading ages and national profile levels; facilitates appropriate teaching strategies; and provides for recording of qualitative information. The range of the NARA is 6-12 years of age and special needs students through to adult level. Reading speed provides an index of the child's normal reading speed, which is converted to the number of words read per minute. Reading accuracy is the number of errors accumulated when reading the passages, and reading comprehension involves assessment of what the child remembers regarding the content of the passages (Denton, 2007; Grade, 2009).

\subsection{Writing Ability Test}

The ability to write correctly in children is an achievement that gives children great satisfaction. Children ability to write down the right words in the right sequence so that their writing reflect their thoughts and feelings that engages the reader gives them feelings of accomplishment (Briggs et al., 2014). Thus, children were given assignment to set down the right words in the right sequence so that their writings reflect their thoughts and feelings. The children's writing ability tests result should be able to tell their class teachers much more than whether or not a child is coping and ready for future academic exercise. This process also tells the teacher the right academic level of the child and the areas that require interventions.

\section{Methods}

\subsection{Design}

This study adopted a cross-sectional cohort study of primary school aged children in three age groups: 6,7 , and 8 years. It adopted a pre and posttest method to be able to arrive at a dependable assessment scale. The pretest results were retrieved in the $2^{\text {nd }}$ term while that of the posttest was retrieved in the $3^{\text {rd }}$ term of 2013 .

\subsection{Participants}

The sample comprised 321 nursery and primary school children (121 male, 200 females) from the Rivers State of Nigeria ranging in age from 6 to 8 years (see Table 1). Eleven public schools were selected arbitrarily out of the hundreds from the Ahoada East and Ahoada West local government areas. Active parental and school authority consent was sought for each child as prescribed by professional and institutional ethics governing academic research (Briggs et al., 2012). Children were issued a simple consent form for their parents to complete and return stating their willingness for their child to participate in the study. No diagnosis of mental retardation (e.g., IQ or neurological anomalies or epilepsy, traumatic brain injury) was conducted before the study commenced. All the pupils tested spoke English as a second language. Data for this study were collected between the beginning of $2^{\text {nd }}$ term and the end of $3^{\text {rd }}$ term (January-August) 2013.
Table 1. Descriptive Statistics of Pupils' Demographic Variables

\begin{tabular}{llll}
\hline Variable & & Frequency $(\mathbf{n})$ & Percent $(\boldsymbol{\%})$ \\
\hline Gender & Female & 200 & 62.3 \\
& Male & 121 & 37.7 \\
Total & & 321 & 100.0 \\
Age & 6 years & 104 & 32.4 \\
& 7 years & 136 & 42.4 \\
& 8 years & 81 & 25.2 \\
Total & & 321 & 100.0 \\
\hline
\end{tabular}

\subsection{Procedure}

Various class teachers, were trained on how to administer the tests to their pupils. The teachers were given two days training on how to administer test effectively and record scores accurately. The test followed standard administration guidelines. Children were individually pre and post-assessed during their normal classrooms sessions in their reading and writing lessons. The various class teachers completed the DII test form on behalf of the children.

\subsection{Data Analysis}

The analyses for this study were based on standard mean score and a standard deviation (SD). The DII standard scores were calculated using descriptive data from a normative study of primary school children from the selected schools. No child tested had incomplete data. Statistical Package for the Social Sciences 21 (SPSS) was used to determine whether significant differences existed between the pattern of reading and writing measures and the completeness in reading and writing measures. A complete data set was created and used in the analyses. A diverse range of statistical techniques was used for data analysis: mean, SD, One-Way Analysis of Variance (ANOVA) $(F)$, and $t$-test $(t)$ analyses. ANOVA was employed to examine relationships between the reading and writing measures based on diligence and intelligence (Hypotheses 1 and 2). The $t$-test was used to determine whether correlation of diligence is significantly higher than that of intelligence (Hypothesis 3).

The DII instrument reliability test was in strict accordance with reliability theory (Cronback, Gleser, Nanda, \& Rajarratnam, 1972). To this end, the reliability test was used to determine the percentages of variance in the distribution of scores obtained from tests that can be attributed to the true scores and to determine the standard error of measurement in the full range of scores obtained in the test (Briggs et al., 2014; Kpolovie, 2010). Thus, the internal consistency of the DII was investigated by Cronbach's alpha coefficients and an estimate of .872 (pre-test) and .898 (post-test) was achieved, giving a strong reliability measure.

\section{Results/Discussion}

\subsection{Diligence and Intelligence as Predictors for Reading and Writing Ability in Children}

This study first aimed at determining whether significant difference exists in the pretest and posttest scores of 
diligence and/or intelligence as predictors of reading and writing ability for children aged 6,7 , and 8 years. The descriptive statistics (mean and SD) scores are presented in Table 2.

The posttest scores for reading (29.31) and writing (30.23) were higher than those of the pretest for reading (29.99) and writing (26.51). The data also depict a total increase from 56.50 for pretest to 59.54 for posttest in both reading and writing scores combined.

The pretest mean score of the participants in the intelligence scale based reading revealed an increase from 17.00 to 20.16 , while the posttest scores revealed a decrease from 26.50 to 20.30. However, the total mean scores for intelligence show a slight increase from 43.50 to 40.47 . Overall, there is a significance difference in the mean rating of participants' pretest scores for diligence (56.50) and intelligence (43.50) in reading and writing. The same is true for the posttest scores for diligence (59.54) and intelligence (40.47) in reading and writing.

Table 2. Mean and Standard Deviation of Pupils'Diligence and Intelligence Scores Based on Reading and Writing

\begin{tabular}{ccccccc}
\hline \multirow{2}{*}{ Variables } & \multirow{2}{*}{ Factors } & \multirow{n}{*}{} & \multicolumn{2}{c}{ Pre-test } & \multicolumn{2}{c}{ Post-test } \\
\cline { 4 - 7 } & & $\bar{x}$ & SD & $\bar{x}$ & SD \\
\hline \multirow{2}{*}{ Diligence } & Reading & 321 & 29.99 & 6.21 & 29.31 & 6.69 \\
& Writing & 321 & 26.51 & 7.44 & 30.23 & 6.24 \\
& Total & 321 & 56.50 & 3.65 & 59.54 & 12.93 \\
& Reading & 321 & 17.00 & 7.81 & 20.16 & 6.61 \\
Intelligence & Writing & 321 & 26.50 & 6.89 & 20.30 & 6.43 \\
& Total & 321 & 43.50 & 4.79 & 40.47 & 13.04 \\
\hline
\end{tabular}

To verify our analytical information further, an ANOVA analysis of the data was conducted. The ANOVA analysis was aimed at determining if diligence and/or intelligence would be a predictor of reading and writing ability for children of the ages of 6, 7, and 8 years (Hypotheses 1 and 2) using the participating children means. The variables were measured as they appeared in the questionnaire.

The results showed that the children's diligence is a higher predictor for reading and writing abilities than intelligence is. SPSS version 21 displayed it as $p<.000$ and $p<.025$ significant levels, respectively for reading and writing. This does not mean that the probability is 0 ; it is less than .0005 .
Table 3 shows the $F$-value for the pretest as $p<.025$ and the $F$-value for the posttest at $p<.000$. This means that both the pretest and posttest analysis revealed that children's reading and writing ability is more predicted on diligence. This finding shows that "practice makes perfect". Although children are never perfect readers, practicing helps them improve their reading skills and their confidence (Sean, 2014).

Diligence practices had a higher effect on both the reading and writing abilities of the participating students. The efficacy levels of children towards reading and writing both at home and in classes is rewarding. The results in Table 3 show that the teachers-support-based practices had a greater effect on children self-efficacy levels in reading and writing than the children's intelligence-based activity and abilities (Seigile, n.d.).

In line with Shead's (2010) argument, reading is the foundation of early education. The majority of the world's knowledge is locked away in books. The ability to access this knowledge is related directly to intelligence and of how diligent one is in reading exercises. Reading is a skill that both children and adults carry out, and the ability to read complex material is increased by stretching one's self and doing it diligently. In addition, Shead (2010) noted that writing is the process of synthesizing new thoughts from knowledge and experience. Writing is the systematic refinement of thought; it captures fleeting ideas, small inspirations, and unique insights in a way that can be shared, remembered, and analyzed. Writing is how we clarify our thoughts. In fact, most people have difficult time forming complex ideas if they try to do it only in their mind.

The practice of writing leads to the exercise of thoughts in ways that are very difficult to do without getting them down on paper. To take advantage of writing as an exercise, one must do it often and on a regular basis. However, writing can be very hard work and many people stop trying simply because it is difficult. Most people who have any skill at writing only got that way by pushing through the difficulties and continuing to improve their skill (Yamashita, 2013). According to Chang and Millett (2013) and Walker (2012), no matter the age or grade level of children, diligent writing practices boost both skill and comfort level.

Table 3. ANOVA Analysis of Diligence/Intelligence as Predictor of Reading and Writing Ability for Children

\begin{tabular}{|c|c|c|c|c|c|c|}
\hline \multicolumn{7}{|c|}{ ANOVA } \\
\hline & & Sum of Squares & df & Mean Square & $\mathbf{F}$ & Sig. \\
\hline \multirow{3}{*}{$\begin{array}{c}\text { Pre-test } \\
\text { Diligence/Intelligence }\end{array}$} & Between Groups & 3.320 & 2 & 1.660 & 3.743 & .025 \\
\hline & Within Groups & 141.035 & 318 & .444 & & \\
\hline & Total & 144.355 & 320 & & & \\
\hline \multirow{3}{*}{$\begin{array}{c}\text { Post-test } \\
\text { Diligence/Intelligence }\end{array}$} & Between Groups & 13.347 & 2 & 6.673 & 13.201 & .000 \\
\hline & Within Groups & 160.753 & 318 & .506 & & \\
\hline & Total & 174.100 & 320 & & & \\
\hline
\end{tabular}

\subsection{Difference in Children's Reading and Writing Success Based on Diligence and Intelligence}

Data from the paired $t$-test analysis aimed at testing whether differences exists in 6, 7, and 8-year-old school children's reading and writing success usually has to do with diligence rather than intelligence. As presented in Table 4, the pretest and posttest mean scores of the participants were significantly different; the results show a dissimilarity in the pretest result for diligence and intelligence $(t=6.186, p<$ 
$=.030)$ and the posttest results for diligence and intelligence in reading and writing $(t=13.065, p<.002)$.

Examining the results in terms of effect, the difference in the participating children's scores from the pretest and posttest analysis in their reading and writing abilities based on diligence and intelligence was significantly different; thus, diligence had a larger effect on children's reading and writing success during the posttest analysis $(p<.002)$. Specifically, the results revealed that children's reading and writing success usually has to do with diligence rather than intelligence. Thus, hypothesis three was accepted.

Overall, we found a significant difference in the reading and writing abilities of the children based on age $(p<.000)$ and gender $(p<.000)$. Furthermore, the majority of boys performed to expectation in their reading and writing classroom activities during the period when we were carrying out this study. However, it is a fact that boys are more likely than girls are to have learning challenges or to achieve at a level below than their potential (Younger et al., 2005; National Literacy Trust, 2012). This is partly because boys are more likely than girls to show slight discomfort in their academic work in reading and writing, but also because there is an obvious tendency for some boys simply to be less interested in the reading and writing skills of some classroom activities. This insignificant group of boys is more interested in extracurricular activities; as a result, they become increasingly uninterested with classroom reading and writing activities (Stenhouse, 2009).

Table 4. Paired Samples T-Test Analysis of the Pretest and the Posttest Scores of Children Diligence and Intelligence on Reading and Writing Ability

\begin{tabular}{|c|c|c|c|c|c|c|c|}
\hline & & \multicolumn{3}{|c|}{ Paired Differences } & \multirow{2}{*}{$\mathbf{t}$} & \multirow{2}{*}{ df } & \multirow{2}{*}{ Sig. (2-tailed) } \\
\hline & & Mean & SD & Std. Error Mean & & & \\
\hline Pre-test & Diligence-Intelligence & 14.375 & .7629 & .06576 & 7.186 & 320 & .030 \\
\hline Post-test & Diligence-Intelligence & 19.375 & .6091 & .06322 & 13.065 & 320 & .002 \\
\hline
\end{tabular}

\section{Final Thoughts}

In today's world, young children look for attention and engage in positive or even negative behaviour to attain it. It is important that teachers recognize the diligence and intelligence worth of their students on a consistent basis. Students should feel as though they are important and appreciated to contribute in classroom activities constructively. To send this message, teachers should not simply dole out praise over any minimal achievement or use the same statement of praise for every task (Asraf \& Ahmad, 2003).

Diligent and intelligent children have the potential to succeed. However, many students become incredibly frustrated and have difficulty coping with the discrepancies between their diligence and intelligence and their reading and writing abilities. Their struggle to cope with the frustration they encounter often leaves them feeling inadequate, disappointed, and angry, all of which might affect their ability negatively. A number of diligent and intelligent children are confused about where they fit in among their peers, and often struggle with the social skills needed to maintain positive academic and peer relationships. Teachers and parents must acknowledge their children's ability, as well as their needs and reorganize their strength and limitations so that they can better prepare for the task ahead. However, teachers, who are at the core of children educational development, must aim to strengthen their pupil's academic abilities and nurture these abilities while also supporting them where the need comes within and outside the classroom To do all these, teachers must have the opportunities to tap the full potentials of both the diligent and the intelligent children. Failure on their part to tap into their pupils' potentials fully might result to severe and grave consequences (Brody \& Mills, 1997).
Teachers who teach children should be able to design and organize reading and writing exercises and better assessment procedures, which is based upon a thorough knowledge of the reading and writing skills of their pupils. They should use appropriate, effective classroom reading and writing practices to create and manage great and dynamic learning environment. Finally, teachers should demonstrate strong oral communication and writing skills and employ effective reading and writing tactics and methods.

Much work remains to be done in understanding the impact of diligence and intelligence in children's reading and writing abilities. This unique study in the area of diligence and intelligence has implications that can soften the progress in the understanding of the issues surrounding children's reading and writing success. This study has given extensive awareness to the divergent views of the impact of diligence and intelligence in children's academic developmental stride. As such, this study might fill an intellectual fissure in understanding the key issues surrounding early children achievement in reading and writing skills from a developing country's perspective.

This study breaks new academic disposition by focusing on the impact of diligence and intelligence in children's literacy, which is under-researched in the developing world aside from this work. This study has implications for actors in early childhood education, schools, family, policy makers, and government in Africa in general and in Nigeria, in particular. This study encourages early childhood teachers and strategic education planners to explore 'best practices' to improve and support teaching processes in children. We would caution that this study is a means to guide valid and reliable diligence and intelligence researchers in the direction to look during their research endeavors. Thus, we recommend extensive research on the theme of this study. 


\section{References}

[1] Asraf, R. M., \& Ahmad, I. S. (2003). Promoting English language development and the reading habit among students in rural schools through the Guided Extensive Reading program. Reading in a Foreign Language, 15(2), 83-102.

[2] Bay, C. S. (2009). How to teach children diligence. Retrieved from http://www.helium.com/items/1479245-teachingchildren-diligence

[3] Briggs, T., Ololube, N. P., \& Kpolovie, P. J. (2014). Managing children learning: support based screening procedure for motor, cognition and language communication in early childhood education. International Journal of Management in Education, 8(2), 168-193. doi: 10.1504/IJMIE.2014.060234.

[4] Briggs, T., Ololube, N. P., Kpolovie, P. J., Amaele, S., \& Amanchukwu, R. N. (2012). Evaluating the quality of public early childhood education and Vision 20: 2020: the role of government. African Journal of Economic and Sustainable Development, $\quad 1(3), \quad 243-264 . \quad$ doi: 10.1504/AJESD.2012.049289

[5] Brody, L. E., \& Mills, C. J. (1997). Gifted children with learning disabilities: a review of the issues. Journal of Learning Disabilities, 30(3), 282-286.

[6] Carless, D. (2004), Issues in Teachers' Reinterpretation of a Task-Based Innovation in Primary Schools. TESOL Quarterly, 38(4), 639-662. doi: 10.2307/3588283.

[7] Carless, D. (2009). Learning-oriented assessment: Principles, practice and a project. In L. H. Meyer, S. Davidson, H. Anderson, R. Fletcher, P. M. Johnston, \& M. Rees (Eds.), Tertiary Assessment \& Higher Education Student Outcomes: Policy, Practice \& Research (pp.79-90). Wellington, New Zealand: Ako Aotearoa.

[8] Chall, J. S., \& Jacobs, V. A. (1983). Writing and Reading in the Elementary Grades: Developmental Trends Among Low SES Children. Language Arts, 60(5), 617-626.

[9] Chang, A. C. S., \& Millett, S. (2013). Improving reading rates and comprehension through timed repeated reading. Reading in a Foreign Language, 25(2), 126-148.

[10] Colbert, J. (2008). Brain Development Research Can Influence Early Childhood Curriculum. Retrieved from http://www.earlychildhoodnews.com/earlychildhood/article_v iew.aspx?ArticleID $=245$

[11] Cotton, S. M., \& Crewther, S. G. (2009). The Relationship Between Reading and Intelligence in Primary School Aged Children: Implications for Definitional Models of Dyslexia. The Open Education Journal, 2, 42-50.

[12] Cronback, L. J., Gleser, G., Nanda, H., \& Rajarratnam, N. (1972). The dependability of behavioural measurement. New York, NY: Willey.

[13] Dewar, G. (2013). Harmful beliefs: How a theory of intelligence can hamper your child's ability to learn. Retrieved from http://www.parentingscience.com/theory-ofintelligence.html

[14] Driscoll, M. (2001). Psychology of learning for assessment (2nd ed.). Boston. MA: Allyn and Bacon.
[15] Dweck, C. S. (2006). Mindset: The new psychology of success. New York, NY: Random House.

[16] Eliasmith, C. (Ed.) (2001). Memory. Dictionary of philosophy of mind. Pullman, WA: Washington State University.

[17] Elliot, A., \& Dweck, C. S. (2005). Handbook of competence and motivation. New York, NY: Guilford.

[18] Fisher, T. (2013). Teach to Each Child's Intelligence. Retrieved from http://www.huffingtonpost.com/thomasfisher/teach-to-each-childs-inte_b_2251444.html

[19] Flowers, L., Meyer, M., Lovato, J., Wood, F., \& Felton, R. (2000). Does third grade discrepancy status predict the course of reading development? Ann Dyslexia, 50, 49-71.

[20] Flynn, J. (2011). Writing is a uniquely human activity; and therefore, a wonder to watch develop. Retrieved November 11 , 2014 from http://www.fundanoodle.com/blog/writing-is-auniquely-human-activity-and-therefore-a-wonder-to-watchdevelop.

[21] Gardner, H. (1983), Frames of mind: the theory of multiple intelligences. New York, NY: Perseus Books.

[22] Gustafson, S., \& Samuelsson, S. (1999). Intelligence and dyslexia: Implications for diagnosis and intervention. Scandinavia Journal of School Psychology, 40, 127-134.

[23] Harrison, C. (2004). Understanding reading development. London: Sage Publications.

[24] Hashmi, F. K. H. (n.d.). Reading. Retrieved from http://www.hrmars.com/admin/pics/82.pdf

[25] http://www.earlychildhoodnews.com/earlychildhood/article_v iew.aspx?ArticleID $=245$

[26] Hu, R. (2009). English Reading Instruction in Elementary Schools in China. The Reading Matrix, 9(2), 150-165.

[27] Huttenlocher, J., Haight, W., Bryk, A., Seltzer, M., \& Lyons, T. (1991). Early Vocabulary Growth: Relation to Language Input and Gender. Developmental Psychology, 27(2), 236-248. doi:10.1037/0012-1649.27.2.236.

[28] Jablon, J. R., \& Wilkinson, M. (2006).Using Engagement Strategies to Facilitate Children's Learning and Success. Retrieved November 14, 2014 from https://www.naeyc.org/files/yc/file/200603/JablonBTJ.pdf.

[29] Japanese Education. (n.d.). Hard work, diligence, and perseverance. Retrieved from http://members.tripod.com/h_javora/jed1.htm.

[30] Junkere, B. (2009). How to teach children diligence. Retrieved from http://www.helium.com/items/1478894teaching-diligence

[31] Klein, P. D. (1997). Multiplying the problems of intelligence by eight: a critique of Gardner's Theory. Canadian Journal of Education, 22(4), 377-394.

[32] Kpolovie, P. J. (2010). Advanced Research Methods. Owerri, Nigeria: Springfield Publishers.

[33] Langer, J. A. (1986a). Children Reading and Writing: Structures and Strategies. Norwood, NJ: Ablex.

[34] Langer, J. A. (1986b). Learning through writing: Study skills in the content areas. Journal of Reading, 29, 400-406. 
[35] Li, C. (2008). How to teach your preschool child the alphabet and reading. Retrieved from http://www.helium.com/items/784542-how-to-teach-yourpreschool-child-the-alphabet-and-reading

[36] Li, J. (2005). Mind or Virtue: Western and Chinese beliefs about learning. Current Directions in Psychological Science, 14(4), 190-194.

[37] Lily, A. (n.d.). Successful homeschooling, it depends on you, give it time and diligence. Retrieved from http://EzineArticles.com/2019482

[38] Lutz, S., \& Huitt, W. (2003). Information processing and memory: Theory and applications. Educational Psychology Interactive. Valdosta, GA: Valdosta State University. Retrieved from http://www.edpsycinteractive.org/papers/infoproc.pdf

[39] Lyon, G. R. (1995). Towards a definition of dyslexia. Ann Dyslexia, 45, 3-27.

[40] Mae, J. (2010). How to teach children diligence. Retrieved from http://www.helium.com/items/1920861-diligenceteaching-childrenteaching-stategies-parenting

[41] Mangels, J. A., Butterfield, B., Lamb, J., Good, C., \& Dweck, C. S. (2006). Why do beliefs about intelligence influence learning success? A social cognitive neuroscience model. Social Cognitive Affective Neuroscience, 1(2), 75-86. doi: 10.1093/scan/ns1013

[42] McGrew, K. S., \& Evans, J. (2004). Expectations for students with cognitive disabilities: Is the cup half empty or half full? Can the cup flow over? (Synthesis Report 55). Minneapolis, MN: University of Minnesota, National Center on Educational Outcomes. Retrieved from http://education.umn.edu/NCEO/OnlinePubs/Synthesis55.htm 1

[43] McLeod, S. (2009). Jean Piaget. Retrieved November 11, 2014 from http://www.simplypsychology.org/piaget.html.

[44] Meyer, M. (2000). The ability-achievement discrepancy: does it contribute to an understanding of learning disabilities. Educational Psychology Review, 12(3), 315-37.

[45] Mudzielwana, N. P. (2012). Causal Factors of Low Reading Standards of the Foundation Phase Learners in Vhembe District, Limpopo Province of South Africa. Journal of Research in Education and Society, 3(1), 117-127.

[46] National Literacy Trust (2012). Boys' Reading Commission. Retrieved May 26, 2014 from http://www.literacytrust.org.uk/assets/0001/4056/Boys_Comm ission_Report.pdf.

[47] Neale, M. D. (1991). Neale analysis of reading ability revised - manual. Hawthorn, Victoria: Australian Council for Education Research.

[48] Neale, M. D. (1999). Neale analysis of reading ability (3rd ed.). Hawthorn, Victoria: ACER Press.

[49] Neisser, U. (1995). Selected Portions of Intelligence: Knowns and Unknowns. Retrieved from http://webspace.ship.edu/cgboer/iku.html

[50] Neisser, U., Boodoo, G., Boucard, T. J., Boykin, A. W., et al (1996). Intelligence: Knowns and Unknowns. American Psychologist, 51(2), 77-101.
[51] NEPS. (2012). Effective Interventions for Struggling Readers: A Good Practice Guide for Teachers. Retrieved from http://www.education.ie/en/Education-

Staff/Information/NEPS-Literacy-

Resource/neps_literacy_good_practice_guide.pdf

[52] Oakley, G., \& Barratt-Pugh, C. (2007). The Identification of Assessment Resources to Support Children Learning to Read in the Early Years of School: Literature Review. Perth, Australia: Edith Cowan University. Retrieved from http://www.decd.sa.gov.au/farnorthandaboriginallands/files/lin ks/191207_Assessmt_Final_lite.pdf

[53] Ololube, N. P., Briggs, T., Kpolovie, P. J., \& Ezindu, S. A. U. (2010). Communicative Approach as a Tool for Relating Reading and Writing Skills in Early Childhood Education. Discourse and Communication for Sustainable Education, $1(2), 34-54$.

[54] Ololube, N. P., Kpolovie, P. J., \& Egbezor, D. E. (2009). Education Policy Analysis: The Need to Accelerate and Redesign Early Childhood Education Preparation Programs. International Journal of Education, Economics and Development, $\quad 1(2), \quad 118-141 . \quad$ doi: 10.1504/IJEED.2009.029304

[55] Ozenreider, A. (n.d.). Developing written language skills in your preschooler. Retrieved from http://www.sixtysecondparent.com/_webapp_292070/Develop ing_written_language_skills_in_your_preschooler.

[56] Paris, S. C., \& Hoffman, J. V. (2004). Reading assessments in kindergarten through first grade: Findings from the Center for the Improvement of Early Reading Achievement. The Elementary School Journal, 105(2), 199-217.

[57] Perfetti, C. (2007). Reading Ability: Lexical Quality of Comprehension. Scientific Studies of Reading, 11(4), 357-383.

[58] Save the Children (2002). Schools for All: Including disabled children in education. Retrieved May 26, 2014 from http://www.eenet.org.uk/resources/docs/schools_for_all.pdf.

[59] Scarborough, H. S., \& Parker, J. D. (2003). Matthew effects in children with learning disabilities: Development of reading, IQ, and psychosocial problems from grade 2 to grade 8 . Annals Dyslexia, 53, 47-71.

[60] Scruton, H., \& McNamara, J. (2014). Using Motivational Tactics to Support Children with Reading Disabilities. International Journal of Elementary Education, 3(4), 92-97. doi: 10.11648/j.ijeedu.20140304.11.

[61] Sean, S. (2014). Providing Support for Your Dyslexic Child. Retrieved from https://learningbreakthrough.com/learningbreakthrough-blog/providing-support-dyslexic-child/

[62] Seigile, M. (n.d.). Just For Youth... Is Intelligence the Most Important Factor for Success? Retrieved March 20, 2014 from http://www.ucg.org/christian-living/just-youthintelligence-most-important-factor-success/.

[63] Shead, M. (2010). Your Intelligence - Reading, Writing \& Arithmetic. Retrieved from http://www.productivity501.com/intelligence-reading-writingarithmetic/6895/

[64] Siegel, L. S. (2003). IQ-discrepancy definitions and the diagnosis of LD: introduction to special issue. Journal of Learning Disability, 36(1), 2-3. 
114 Teinye Briggs and Nwachukwu Prince Ololube: Does the Differences in 6, 7, and 8-Year-Old Children's Reading and Writing Success has to do With Diligence Rather Than Intelligence

[65] Song, M., \& Young, T. (2008). Reading: policy, politics and processes. Charlotte, NC. Information Age Publishing.

[66] Stage, S. A., Abbott, R. D., Jenkins, J. R., \& Berninger, V. M. (2003). Predicting response to early reading intervention from verbal IQ, reading related language abilities, attention ratings, and verbal IQ-word reading discrepancy: Failure to validate discrepancy method. Journal of Learn Disability, 36(1), 24-33.

[67] Stenhouse, G. (2009). Learning difficulties in children. Retrieved November 11, 2014 from http://www.kidzgrow.com.my/forum/viewthread.php?tid=32.

[68] Sternberg, R. J. (1983). How much Gall is too much gall? Review of frames of mind: The theory of multiple intelligences. Contemporary Education Review, 2(3), 215-224

[69] Sternberg, R. J. (1991). Death, taxes, and bad intelligence tests. Intelligence, 15(3), 257-270.

[70] Tough, P. (2011). What if the Secret to Success Is Failure? November 14, 2014 from http://www.nytimes.com/2011/09/18/magazine/what-if-thesecret-to-success-is-failure.html?pagewanted=all\&_r=0.
[71] Vellutino, F. R., Scanlon, D. M., \& Lyon, G. R. (2000). Differentiating between difficult-to-remediate and readily remediated poor readers: More evidence against the IQachievement discrepancy definition of reading disability. Journal of Learning Disability, 33(3), 223-38.

[72] Walker, S. (2012). 5 Reasons Why Your Students Should Write Every Day. Retrieved from http://www.scilearn.com/blog/5-reasons-students-shouldwrite-every-day.php

[73] Williams, B., Myerson, J., \& Hale, S. (2008). Individual Differences, Intelligence, and Behavior Analysis. Journal of the Experimental Analysis Behavior, 90(2), 219-231. doi: 10.1901/jeab.2008.90-219

[74] Yamashita, J. (2013). Effects of extensive reading on reading attitudes in a foreign language. Reading in a Foreign Language, 25(2), 248-263.

[75] Younger, M., Warrington, M., Gray, J., Rudduck, J., McLellan, R., Bearne, E., Kershner, R., \& Bricheno, P. (2005). Raising Boys' Achievement. Cambridge: University of Cambridge Faculty of Education 